\title{
Changes of Mastoid Gas Physiology in Virtual Mastoidectomy Model
}

\author{
Dae Han Chung, Hoon Jung, Eun Woong Ryu, Cheol Eon Park, \\ Jae Yong Byun, Seung Geun Yeo and Moon Suh Park \\ Department of Otorhinolaryngology-Head and Neck Surgery, School of Medicine, Kyung Hee University, Seoul, Korea
}

\section{가상 유양동삭개술 모델에서 유양동 기체 생리의 변화}

\author{
정대한 · 정 훈 · 류은웅 · 박철언 · 변재용 · 여승근 · 박문서 \\ 경희대학교 의과대학 이비인후과학교실
}

\section{Received February 2, 2010 \\ Revised April 8, 2010 \\ Accepted April 19, 2010}

Address for correspondence Moon Suh Park, MD

Department of OtorhinolaryngologyHead and Neck Surgery,

School of Medicine,

Kyung Hee University,

149 Kangdong-gu, Sangil-dong

Seoul 134-727, Korea

Tel +82-2-440-6179

Fax +82-2-440-7321

E-mail pmsuh@yahoo.co.kr
Background and Objectives It is essential to understand gas physiology of mastoid cavity to study the pathophysiology of middle ear diseases, and the surface area and volume of mastoid mucosa are important parameters for evaluating gas physiology. However, the surface area and mastoid volume of the mastoid cavity have not been practically measured yet. Therefore, we measured and compared surface area and volume of the mastoid cavity before and after mastoidectomy using a virtual mastoidectomy model.

Subjects and Method We performed a virtual mastoidectomy using 10 cases of temporal bone CT indicating pneumatic mastoid. First, we removed all air cells after outlining with irregular AOI function after loading axial CT images to Image-Pro Plus 4.0. Then we filled the removed area with equal planes using local equalization filter. Finally, we calculated and compared the total surface area, volume and area to volume $(\mathrm{A} / \mathrm{V})$ ratio by estimating their circumference and area.

Results The mean surface area of pneumatized mastoid cavity was $127.8 \mathrm{~cm}^{2}$ (range: $94.2-$ $165.3 \mathrm{~cm}^{2}$ ), and the mean volume was $7.1 \mathrm{~cm}^{3}$ (range: $5.2-11.0 \mathrm{~cm}^{3}$ ). The mean surface area and volume were altered to $42.8 \mathrm{~cm}^{2}$ (range: $35.9-55.0 \mathrm{~cm}^{2}$ ) and $12.6 \mathrm{~cm}^{3}$ (range: $10.3-18.7$ $\mathrm{cm}^{3}$ ), respectively, after virtual mastoidectomy. As a result, the A/V ratio decreased from 18 to 3.4 after a virtual mastoidectomy in the pneumatic mastoid cavity.

Conclusion When a complete mastoidectomy is performed in the pneumatic mastoid, the surface area is decreased by one third compared to a relatively minor increase in volume. Therefore, the surface area per unit volume is expected to greatly decrease after mastoidectomy. Some physiologic problems occurring after mastoidectomy could be more accurately explained using a virtual mastoidectomy model. Korean J Otorhinolaryngol-Head Neck Surg 2010;53:284-9

Key Words Mastoid · Mastoidectomy · Surface area · Volume.

\section{서 론}

유양동 함기세포(mastoid air cell system)는 무수한 기 낭으로 이루어진 구조물로 유양동 기체 완충(air buffer) 기 능과 기체 생산 기능을 담당하여 중이강의 생리에 중요한 역할을 하는 것으로 알려져 있다. ${ }^{1,2)}$ 이러한 기능을 유지하기 위해서는 정상 유양동 함기세포는 다중 상호 연결된 기낭 (multiple interconnected air space)으로 구성되어 높은 표면적 대비 부피비 (surface area to volume ratio, $\mathrm{A} / \mathrm{V}$ )를 가지는 구조로 이루어져 있다. ${ }^{3)}$

폐쇄형 유양동 삭개술은 만성 중이염 환자에서 합병증을 예방하고 청력을 개선시키기 위하여 시행한다. 또한 염증 산 물을 배출시키고 유양동의 용적을 증가시켜 ${ }^{4)}$ 유양동의 기체 완충 기능, 기체 생산 기능과 같은 정상 기능을 회복시키기 
위하여 시행한다. 그러나 유양동 삭개술을 시행하게 되면 정 상 해부구조에 변화를 일으켜 유양동의 부피는 증가하고 표 면적은 감소하게 되어 원래의 유양동의 생리적 기능이 변하 게 된다. ${ }^{4)}$ 그러므로 완전한 유양동 삭개술이 유양동의 생리 적 기능을 충분히 회복시킬 수 있는지 또한 함기화된 유양 동에서 중이 염증을 조절하기 위하여 항상 유양동 함기세포 를 완전히 제거하여야 하는가에 대하여는 논란이 있다. ${ }^{5}$

유양동과 중이의 기체생리에 영향을 미치는 인자들은 기 체의 성분, 이관기능, 유양동 점막의 두께, 유양동 점막 혈류 량과 유양동 체적 및 표면적 등이 있다. 이 중에서 유양동의 표면적을 측정하는 것은 유양동 부피와 더불어 기체의 확산 율(diffusion rate)을 측정하는 한 근거가 되므로 유양동의 기체생리를 이해하고 연구하는데 중요한 지표가 되며, 이를 측정하는 방법은 지금까지 여러 가지가 보고 되었다.3,5,6) 본 연구의 목적은 본 교실에서 개발한 가상 유양동삭개술 (virtual mastoidectomy) 모델을 통하여 유양동 함기세포 의 유, 무상태에서 표면적과 부피 변화 및 표면적 대비 부피 비 변화를 측정해 보고자 하였다.

\section{대상 및 방법}

건강한 성인 10 명을 대상으로 연구를 진행하였다. 대상자 의 평균 나이는 35.9세(20 53세)로서, $250 \mathrm{~Hz}$ 에서 8,000 $\mathrm{Hz}$ 까지 양측 $20 \mathrm{~dB}$ 미만의 정상 청력을 가지며, 고실도 검 사에서 -100 에서 $+50 \mathrm{daPa}$ 사이에서 정상적인 첨부를 형성하는 것을 확인하였다. 또한 과거력에서 중이염이나 내 이 질환의 병력을 가진 환자들은 배제하였다(Table 1).

대상자들은 $1 \mathrm{~mm}$ 의 두께로 횡축 컴퓨터 단층촬영 (GE Light speed 16, Milwaukee, USA)을 실시하였으며, 횡 축은 안외이도선(orbitomeatal plane)에 평행하게 촬영하였
다. Window의 범위와 수준은 3,200에서 +400 으로 조정 하였으며, 유양동의 표면적과 부피는 Image-Pro Plus 4.0 software (Media Cybernetics, MD, USA)를 이용하여 계 산하였다.

Park 등5)의 논문을 참조하여 먼저 유양동 함기세포의 표 면적을 구하였는데 그 방법은 다음과 같다. 환자에 따라 48 에서 64 개의 측두골 컴퓨터 단층촬영의 축상면(axial)의 영 상을 얻은 후 Image-Pro Plus 4.0. software (Media Cybernetics, Silver spring, MD, USA)를 이용하여 유양동 에 해당하는 부분을 분리하였다. 각 영상에서 관찰되는 모든 함기세포를 포함하는 부분을 AOI (area of interest)기법을 이용하여 Fig. $1 \mathrm{~A}$ 와 같이 외부둘레를 따라 경계선을 긋고 분리했다. Mastoid antrum, central mastoid tract, peripheral mastoid air cell system을 포함하여 측정하였으나 중이강은 포함하지 않았다. 함기세포들을 주변조직들과 명 확하게 구별하기 위하여 음영의 역치 상한선(upper threshold) 을 65에서 115사이로 조절하였다. 이 threshold level 은 이들 범위가 실제 둘레길이를 나타낸다는 예비실험 결과 에 근거하여 설정한 수치였다. 즉 예비실험으로 함기화가 양호한 영상을 대상으로 하여 threshold level을 변화시켜 가장 실제와 가까운 범위로 함기세포들이 분리되는 지점을 계산하였다.

다음 단계로 분리한 모든 함기세포의 둘레를 프로그램의 Counting and Measurement 도구를 이용하여 측정하였으 며 영상마다 필요에 따라 다양한 edge detection tool을 사 용했다. 즉 함기세포들의 명확한 분리가 어려울 때는 Gaussian curve를 사용하는 Higauss enhancement filter를 이 용하여 미세한 함기세포 벽의 음영을 강조했다.

이러한 방법으로도 측정되지 않았던 누락된 함기세포들은 직접 둘레를 측정하여 포함시켰다. 그 후 해당 plane에서의

Table 1. Characteristics of patients and pre and post mastoidectomy surface area, volume and area to volume ratio (A/V ratio) of mastoid cavity

\begin{tabular}{|c|c|c|c|c|c|c|}
\hline \multirow{2}{*}{ Age } & \multicolumn{3}{|c|}{ Premastoidectomy } & \multicolumn{3}{|c|}{ Postmastoidectomy } \\
\hline & Surface area $\left(\mathrm{cm}^{2}\right)$ & Volume $\left(\mathrm{cm}^{3}\right)$ & A/V ratio $\left(\mathrm{cm}^{-1}\right)$ & Surface area $\left(\mathrm{cm}^{2}\right)$ & Volume $\left(\mathrm{cm}^{3}\right)$ & A/V ratio $\left(\mathrm{cm}^{-1}\right)$ \\
\hline 20 & 94.2 & 5.2 & 18.1 & 35.9 & 10.3 & 3.5 \\
\hline 31 & 165.3 & 11.0 & 15.0 & 55.0 & 18.7 & 2.9 \\
\hline 27 & 131.4 & 7.2 & 18.3 & 40.7 & 13.3 & 3.1 \\
\hline 39 & 153.7 & 8.5 & 18.0 & 50.9 & 15.0 & 3.4 \\
\hline 42 & 125.5 & 6.5 & 19.3 & 42.2 & 12.1 & 3.5 \\
\hline 35 & 141.7 & 7.8 & 18.2 & 49.7 & 13.2 & 3.8 \\
\hline 46 & 121.2 & 6.4 & 18.9 & 41.7 & 11.3 & 3.7 \\
\hline 37 & 100.1 & 5.9 & 17.1 & 36.2 & 10.1 & 3.6 \\
\hline 29 & 126.5 & 6.6 & 19.1 & 38.7 & 11.6 & 3.3 \\
\hline 53 & 118.7 & 6.3 & 19.0 & 37.1 & 10.7 & 3.5 \\
\hline
\end{tabular}



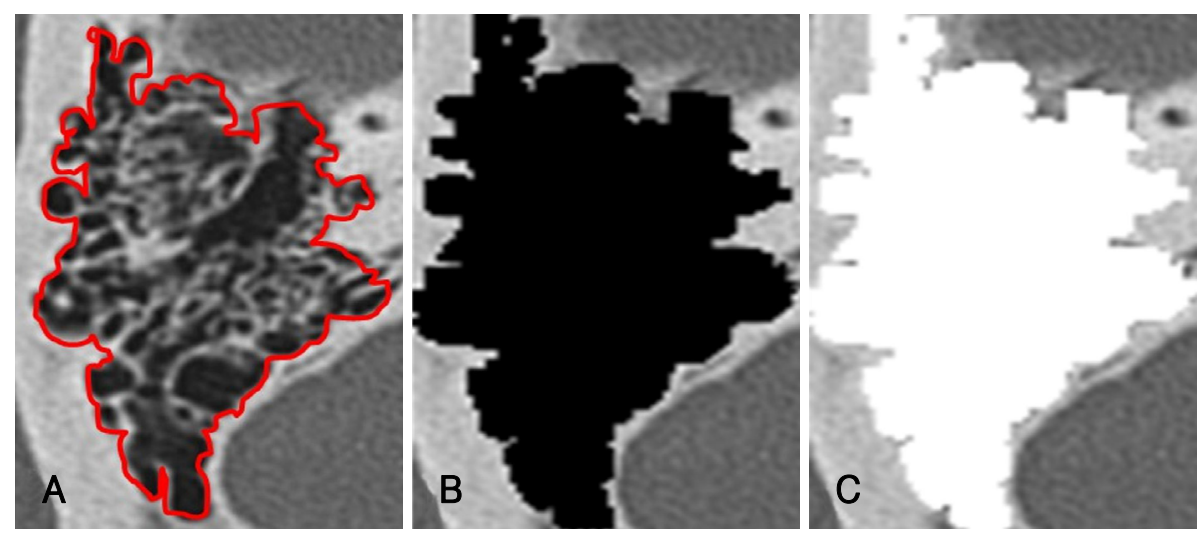

Fig. 1. Process of virtual mastoidectomy. Outlining of perimeters of all the traced air cells $(A)$, erasing designated mastoidectomy area of each image (B) and filling with homogenous plane using local equalization filter (C).

함기세포 둘레의 측정치들을 합산함으로써 총 함기세포의 외곽선 길이를 구하였다. 이 외곽선 길이의 총합에 절편 간 격 $1 \mathrm{~mm}$ 를 곱함으로써 한 plane에서의 함기세포의 내표면 적을 구했고 이 작업을 반복하여 전체를 합산함으로써 전 유양돌기 함기세포의 내표면적을 구했다. 유양동의 부피는 같은 방법으로 분리한 모든 함기세포의 면적을 Counting and Measurement 도구를 이용하여 측정하였다. 이러한 방법으로 각각의 영상에서 함기세포의 면적을 측정한 후 영 상의 두께인 $1 \mathrm{~mm}$ 를 곱하여 합산하는 방법으로 유양동 부 피를 구하였다.

가상 유양동삭개술은 다음과 같이 시행하였다. 측두골 컴 퓨터 단층촬영 각각의 영상에서 Fig. $1 \mathrm{~A}$ 와 같이 관찰되는 모든 함기세포를 포함하는 부분을 AOI(area of interest) 기법을 이용하여 외부둘레를 따라 경계선을 긋고 분리한 후 외부둘레를 따라 선을 긋고 Fig. $1 \mathrm{~B}$ 와 같이 내부의 함 기세포 부분을 Erasing 프로그램을 이용하여 지웠다.

이후에 Fig. $1 \mathrm{C}$ 와 같이 local equalization filter를 이용하 여 내부를 균일한 평면으로 채우고, 각 영상에서 채워진 평 면의 둘레와 면적을 같은 방법으로 구한 후 영상의 두께인 $1 \mathrm{~mm}$ 를 곱하여 합산하는 방법으로 가상 유양동삭개술이 이루어진 유양동의 표면적과 부피를 구하였다.

마지막으로 결과를 가지고 표면적 대 부피비(A/V ratio) 를 산출하였다.

SPSS 윈도우 버전 12.0(SPSS Inc., Chicago, IL, USA)을 이용하였고 2 군을 비교하는 비모수적인 방법인 Wilcoxon signed rank test로 통계분석을 실시하였고 $p$ 값이 0.05 미 만일 경우를 통계적으로 유의한 차이가 있는 것으로 하였다.

\section{결 과}

정상적으로 함기화된 유양동에서 가상 유양동삭개술 수술 전 평균 유양동 표면적은 $127.8 \mathrm{~cm}^{2} \pm 21.9$ (94.2 165.3
Table 2. Mean values and standard deviation of pre and postmastoidectomy surface area, volume and area to volume (A $V$ ratio) of mastoid cavity

\begin{tabular}{lcc}
\hline & Premastoidectomy & Postmastoidectomy \\
\hline Surface area $\left(\mathrm{cm}^{2}\right)$ & $127.8 \pm 21.9$ & $42.8 \pm 6.7$ \\
Volume $\left(\mathrm{cm}^{3}\right)$ & $7.1 \pm 1.7$ & $12.6 \pm 2.6$ \\
A/V ratio $\left(\mathrm{cm}^{-1}\right)$ & $18 \pm 1.3$ & $3.4 \pm 0.3$ \\
\hline
\end{tabular}

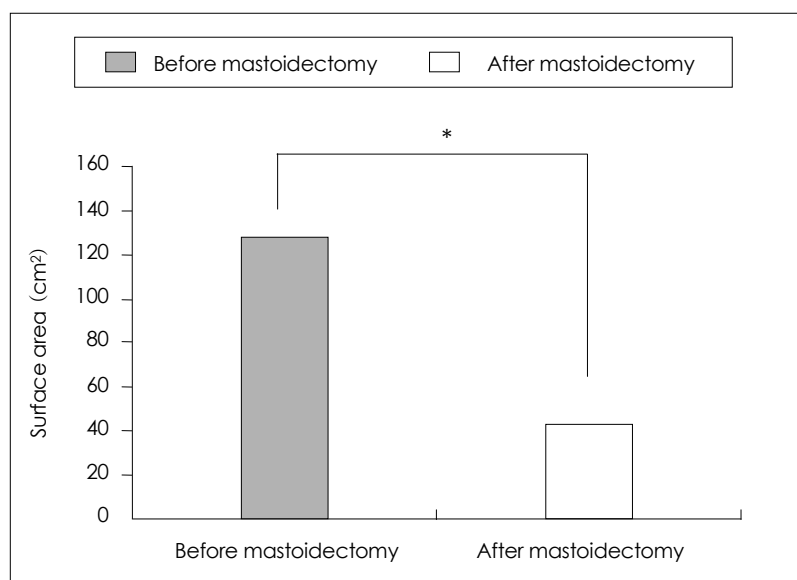

Fig. 2. Changes in surface area after virtual intact canal wall mastoidectomy $(* p=0.005)$.

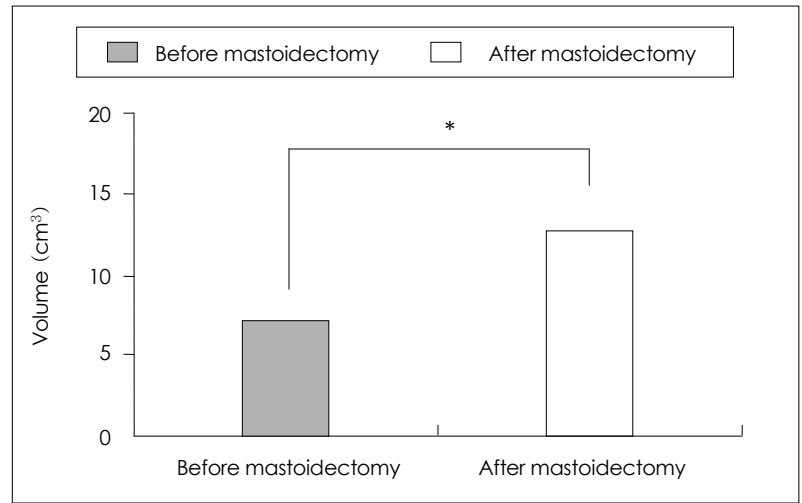

Fig. 3. Changes in mastoid volume after virtual intact canal wall mastoidectomy $(* p=0.005)$. 
$\mathrm{cm}^{2}$ )이었으며, 수술 전 평균 유양동 부피는 $7.1 \mathrm{~cm}^{3} \pm 1.7$ (5.2 11.0 $\mathrm{cm}^{3}$ )이었다. 가상 유양동삭개술 수술 후 평균 유양동 표면적은 $127.8 \mathrm{~cm}^{2} \pm 21.9\left(94.2 \sim 165.3 \mathrm{~cm}^{2}\right)$ 에 서 $42.8 \mathrm{~cm}^{2} \pm 6.7\left(35.9 \sim 55.0 \mathrm{~cm}^{2}\right)$ 로 통계적으로 유의하 게 감소하였으며 $(p=0.005)$, 수술 후 평균 유양동 부피는 $7.1 \mathrm{~cm}^{3} \pm 1.7\left(5.2 \sim 11.0 \mathrm{~cm}^{3}\right)$ 에서 $12.6 \mathrm{~cm}^{3} \pm 2.6(10.3 \sim$ $\left.18.7 \mathrm{~cm}^{3}\right)$ 으로 통계적으로 유의하게 증가하였다 $(p=0.005)$ (Table 1 and 2) (Figs. 2 and 3).

그러나 표면적 대 부피 비의 관점에서 볼 때, 정상적으로 함기화된 유양동에서 가상 유양동삭개술 수술 전 $18 \pm 1.3$ 에서 수술 후 $3.4 \pm 0.3$ 로 통계적으로 유의하게 감소한 결 과를 보였다( $p=0.005$ ) (Table 1 and 2) (Fig. 4).

\section{고 찰}

Fig. 5 에는 3 개의 그림이 있으며 모두 같은 부피를 가지 지만 우측으로 갈수록 표면적이 증가하는 구조로 이루어져 가장 우측의 도형이 함기화된 유양동과 유사한 구조를 갖는 다고 할 수 있다(Fig. 5). 유양동 함기세포는 과거 기체 저 장소(air reservoir)로써 기능이 부각되어 연구되었는데, ${ }^{7)}$ 즉 보일의 법칙(Boyle's Law)에 따라 유양동의 기체저장 은 중이강의 완만한 압력조절을 가능하게 함이 밝혀졌고 이 로 관련하여 유양동의 부피를 측정하는 방법들이 소개되었 다. ${ }^{8,9)}$ 그러나 기체 생리학적인 측면에서 보았을 때 유양동 함기세포는 기체 완충작용(mastoid air buffer) 외에 능동적

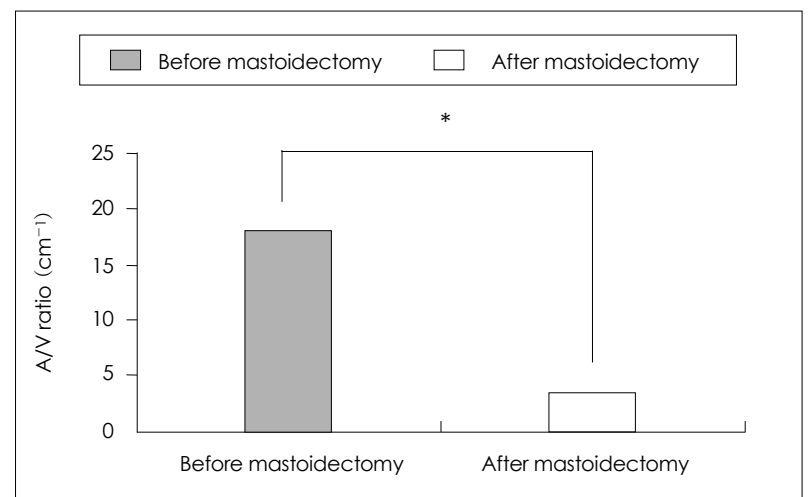

Fig. 4. Changes in area to volume ratio after virtual intact canal wall mastoidectomy $(* p=0.005)$.
인 기체 생산의 역할을 한다고 볼 수 있다. 즉 유양동은 점 막하 모세혈관망을 통하여 기체의 교환이 능동적으로 일어 나는 장소이다. ${ }^{1,5)}$

조직학적으로 사람의 유양동 점막하 조직은 폐나 비강과 같은 구조로 이루어져 있으며, 유양동 함기세포는 혈관이 매 우 풍부한 상피층으로 덮여 있어 기체의 교환이나 확산이 용이한 구조로 이루어져 있다. ${ }^{10,11)}$ 기체 교환은 확산에 의해 일어나는 작용으로 확산이 일어나는 정도는 표면적에 의하여 어느 정도 좌우된다고 할 수 있다. ${ }^{12)}$ 정상 유양동 함기세포 는 다중 상호 연결된 기낭으로 구성되어 높은 $\mathrm{A} / \mathrm{V}$ 를 가지는 구조로 이루어져 있으므로 기체확산에 유리하다. ${ }^{3)}$

그러므로 유양동의 표면적을 측정하는 것은 이러한 유양 동의 기체생리를 이해하고 연구하는 데 중요한 지표가 되며, 이를 측정하는 방법도 최근 여러 가지가 보고 되었다. 즉 측 두골 단층촬영 영상을 이용하여 각 영상에서 유양동 함기세 포들의 모든 둘레(perimeter)를 측정한 후 여기에 영상의 두께를 곱하는 방법이 처음 제시되었고, ${ }^{3,5)}$ 부검한 측두골을 슬라이드로 제작한 후 유양동 함기세포의 둘레를 같은 방법 으로 컴퓨터를 이용하여 측정한 연구가 이어졌다. ${ }^{6)}$ 단층촬 영 영상을 이용한 방법에 비해 측두골 슬라이드를 이용했을 때 더 정확성을 기할 수 있지만 후자는 사체의 측두골 절편 에서만 가능하다는 점, 너무 많은 슬라이드를 대상으로 하므 로 시간이 많이 소비된다는 점에서 임상 데이터를 이용한 연구 방법으로의 유용성은 떨어진다고 하겠다. 본 연구에서 는 측두골 단층촬영 영상을 기반으로 한 방법을 응용하여 가 상 유양동 삭개술 모델을 만들었으며, 이를 통하여 유양동 삭개술 전 후의 표면적과 부피 변화 및 표면적 대비 부피비 변화를 측정하고 그 결과를 분석해보고자 하였다. 방법에 있어 기존의 단층촬영을 이용한 방법과 다른 점은 본 모델 은 영상분석기의 Erasing 기능을 이용하여 각 영상에서 유 양돌기 삭개술 시 제거하는 부분을 각각 지우고 그 지운 부 분만큼의 새로운 plane을 가상으로 그 자리에 채운 후 그 둘 레와 면적을 구하고 그 후 영상의 두께를 곱하여 표면적과 부피를 구했다는 것이다. 술 후 함기세포가 없어졌으므로 측 정 자체는 더 쉬워졌으나 가상으로 새로운 면을 삽입했기 때 문에 가능한 오차는 증가했을 개연성이 있다.

폐쇄형 유양동 삭개술의 생리적 역할은 유양동 함기세포

Fig. 5. Change of the surface area in geometric images with same volume.

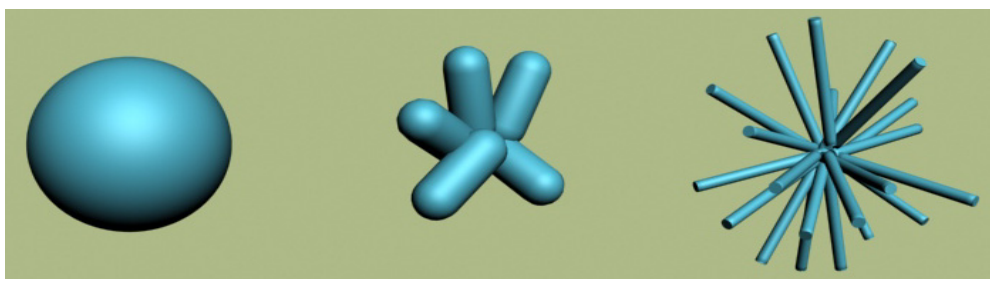


를 모두 제거함으로써 만성 중이염 환자에서 염증 산물을 배 출시키고 유양동의 용적을 증가시켜 중이 통기를 향상시키 는 것이다. 또한 통기상태의 유양동은 중이강 압력을 조절하 고 중이에서 기체 완충기능과 기체 생산 및 교환 기능을 가 능하게 해준다. ${ }^{4,5)}$

그러나 유양동 삭개술을 시행하게 되면 유양동 자체의 부 피는 증가되나 유양동 표면적은 크게 감소되어 기체 확산이 나 교환에 필요한 유양동 면적의 감소로 유양동의 기능은 변 화하게 된다. ${ }^{4}$ 본 연구에서 사용한 가상 유양동삭개술 모델 을 통하여 보았을 때에도 수술 전 평균 유양동 부피가 7.1 $\mathrm{cm}^{3}$ 에서 $12.6 \mathrm{~cm}^{3}$ 로 증가하였으나 평균 유양동 표면적은 수술 전 평균 $127.8 \mathrm{~cm}^{2}$ 에서 $42.8 \mathrm{~cm}^{2}$ 로 $1 / 3$ 로 크게 감소 하였다.

이러한 기하학적인 관점에서 보았을 때, 만성 중이염 환자 에서 정상 함기세포를 포함하여 모든 함기세포를 제거하는 유양동 삭개술이 필요한가에 대하여는 논란이 있다. 더구나 함기화가 잘 된 유양동을 가진 환자에서 완전한 유양동 삭개 술을 시행하는 것은 정상 유양동 생리를 저해할 수 있는 개 연성이 있다. ${ }^{10)}$ 또 유양동 삭개술 후 삭개술을 시행한 공간 이 모두 함기화가 되지는 않는다는 사실도 중요하다. 또한 Okura 등 ${ }^{13)}$ 의 보고에 따르면, 유양동 삭개술 후 유양동 표 면은 모세혈관이 거의 없는 두꺼운 섬유 조직으로 덮이기 때문에 유양동의 기체 교환 기능이 매우 감소하였다고 하였 다. 이와 연계하여 Takahashi 등)은 유양동 점막이 보존된 부위에서는 수술 후 통기가 가능하였다고 보고하였다. 그 러므로 완전한 유양동 삭개술이 유양동의 생리적 기능을 충 분히 회복시킬 수 있는지 또한 함기화된 유양동에서 중이 염증을 조절하기 위하여 항상 유양동 함기세포를 완전히 제 거하여야 하는가에 대하여는 앞으로 많은 연구가 필요하 다. ${ }^{5)} \mathrm{A} / \mathrm{V}$ 는 유양동의 기체생리를 평가하기 위한 척도 중의 하나로 유양동의 압력조절에 결정적인 역할을 한다. 높은 $\mathrm{A} /$ $\mathrm{V}$ 를 가지는 점막은 빠른 기체 교환이 가능하며, 유양동 점막 은 이와 같은 구조로 이루어져 상대적으로 신속한 기체교환 이 가능하다. Magnuson 등 3 은 유양동과 중이의 압력을 조절 하는 데 $\mathrm{A} / \mathrm{V}$ 가 가장 중요한 인자라고 보고했고 Doyle 등 ${ }^{14)}$ 은 중이 기체 생리에 있어서 중요한 인자가 단위 부피당 표 면적과 단위 표면적당 혈류량(blood flow to surface area ratio)이라고 보고하였다. 그러므로 정상적으로 함기화된 유 양동에서 가상 유양동삭개술 전 A/V가 18 에서 수술 후 3.4 로, $80 \%$ 가 감소하는 결과를 보인 것은 술 후 유양동 함기 세포의 단위부피당 유효 표면적량이 크게 감소한 것을 의미 하고 이것은 유양동의 단위부피당 기체 교환 기능이 유양동 삭개술 후 감소하리라는 것을 간접적으로 추측할 수 있게 하
는 결과다. 그러나 유양동 점막의 기체 생리는 $\mathrm{A} / \mathrm{V}$ 외에도 여러가지 지표에 의해 좌우되므로 전체적인 기체생리의 건 전성은 별개로 평가되어야 할 것이다.

함기화된 유양동의 표면적을 측정함에 있어서 매우 얇은 함기세포벽을 정확하게 측정하여 배경 이미지로부터 분리하 여 측정하는 것은 간단한 작업이 아니다. 본 연구에서는 여 러 Edge filter 중에서 Higauss filter를 이용하여 측정하여 오차를 줄이고자 하였다. 또한 과거에 인화된 방사선 필름 을 스캔하여 측정하던 방법에서 컴퓨터상의 이미지로 직접 작업이 가능하여 오차를 더 줄일 수 있었다.

가상 유양동삭개술의 장점은 우선 순수하게 기하학적인 면 만 고려한 유양동 삭개술이 가능하다는 것이다. 즉 유양동 삭 개술 후 발생하는 신생골 혹은 섬유조직 형성을 고려하지 않 아도 되고 항상 모든 유양동 함기세포를 완전히 제거하는 것 이 가능하다는 점이다. 반면 실제 유양동삭개술에서 제거하는 피질골 부분을 고려하지 않은 것은 단점으로 간주될 수 있다.

앞으로 측두골 컴퓨터 촬영의 단층을 더 얇게 한다면 오 차를 조금 더 줄일 수 있을 것으로 생각된다. 또한 함기화가 잘 이루어진 정상 유양동 뿐만 아니라 만성 중이염으로 인 한 판장형(diploic) 혹은 경화형(sclerotic) 유양동에도 본 가상 유양동삭개술 모델을 적용하여 연구한다면, 본 모델이 유양동 기체 생리에 대한 더 많은 연구를 가능하게 하는 도 구가 될 것으로 생각된다. 또 술 후 발생하는 유양동 내 변 화, 즉 섬유조직이나 골조직의 형성, 나아가서는 진주종 재발 등에 관한 시뮬레이션 연구에도 이용될 수 있을 것으로 생 각된다. 그리고 궁극적으로는 $3 \mathrm{D}$ 모델을 구축하여 자동으로 표면적과 부피가 연산될 수 있는 시스템을 갖추는 것이 바 람직할 것이다.

\section{REFERENCES}

1) Ikarashi F, Nakano Y, Okura T. Pneumatization of the tympanic bulla after blockage of the ventilation route through the eustachian tube in the pig. Ann Otol Rhinol Laryngol 1996;105 (10):784-90.

2) Sadé J. The correlation of middle ear aeration with mastoid pneumatization. The mastoid as a pressure buffer. Eur Arch Otorhinolaryngol 1992;249(6):301-4.

3) Magnuson B. Functions of the mastoid cell system: auto-regulation of temperature and gas pressure. J Laryngol Otol 2003;117 (2):99-103.

4) Takahashi H, Honjo I, Naito Y, Miura M, Tanabe M, Hasebe S, et al. Gas exchange function through the mastoid mucosa in ears after surgery. Laryngoscope 1997;107 (8) :1117-21.

5) Park MS, Yoo SH, Lee DH. Measurement of surface area in human mastoid air cell system. J Laryngol Otol 2000;114 (2) :93-6.

6) Oishi T, Ogawa H, Ohtani I. [Computer-aided surface area measurement of temporal bone pneumatization: histological sections.] Nippon Jibiinkoka Gakkai Kaiho 2003;106(3):206-10.

7) Austin DF. On the function of the mastoid. Otolaryngol Clin North Am 1977;10(3):541-7.

8) Frisberg K, Zsigmond M. The size of mastoid air cell system. Planim- 
etry--direct volume determination. Acta Otolaryngol 1965;60:23-9.

9) Colhoun EN, O Neill G, Francis KR, Hayward C. A comparison between area and volume measurement of the mastoid air spaces in normal temporal bones. Clin Otolaryngol Allied Sci 1988;13(1): 59-63.

10) Okubo J, Watanabe I. Physiology and pathophysiology of air-filled ear space and Eustachian tube function. ORL J Otorhinolaryngol Relat Spec 1988;50 (5) :273-305.

11) Ars B, Wuyts F, Van de Heyning P, Miled I, Bogers J, Van Marck E. Histomorphometric study of the normal middle ear mucosa. Preliminary results supporting the gas-exchange function in the postero-su- perior part of the middle ear cleft. Acta Otolaryngol 1997;117(5): 704-7.

12) Ruhl CM, Pensak ML. Role of aerating mastoidectomy in noncholesteatomatous chronic otitis media. Laryngoscope 1999;109(12): 1924-7.

13) Okura T, Nakano Y, Igarashi F. Repneumatization of mastoid after mastoidectomy. Otology (Jpn) 1993;3:639-43.

14) Doyle WJ, Alper CM, Banks JM, Swarts JD. Rate of nitrous oxide exchange across the middle ear mucosa in monkey before and after blockage of the mastoid antrum. Otolaryngol Head Neck Surg 2003; $128(5): 732-41$. 